\title{
Public Private Partnership, an Effective Approach to Leverage the Quality of Public Goods and Services: The Case of Albania
}

\author{
Amalia Tola \\ Phd candidate, Agricultural University of Tirana, Faculty of Economy and Agribusiness \\ Email: amaliatola@hotmail.com

\section{Doi:10.5901/ajis.2015.v4n1p109}

\begin{abstract}
This article aims to explore the concept of Public Private Partnership as an approach that provides mutual benefits to both public and private sectors. Public Private Partnerships are a growing phenomenon in Europe, applied in different sectors. In a context when the public expectations are growing for quality goods and services from the public sector where the funding, knowledge and experience are scarce, these forms of partnerships come very good at hand. As Albania has signed the preaccession agreement with the European Union in 2014, many goods and services provided by the public sectors need to match up to the European standards and improve their quality and value for the money. Albania has great potential to develop successful forms of Public Private Partnerships and the public interest is quite high, however, it is important to learn from own successful and not successful experiences of the past, as well as from the experience of the others. Well defined roles and responsibilities, sharing of risks, mutual understanding for results, transparency and accountability are key to the successful implementation of PPPS.
\end{abstract}

Keywords: Public Private Partnership, Concession, Development, Public Sector, Private Sector

\section{Introduction}

Public Private Partnerships are considered to be an effective model for delivering public goods and services. The need for such form of partnerships rises due to the growing demand in number and quality for goods and services provided by the public sector, which often lacks funding, knowledge and expertise and therefore acquires it through the involvement of the private sector.

Also known with the terms of PPP and 3P, Public Private Partnership experience worldwide is not a new phenomenon, however, it is perceived as such due to the growing interest and expectations of the open public in terms of efficiency, quality and value for money of goods and services delivered.

Although PPPs have existed even earlier, such forms of partnerships received a much stronger interest from both public and privates sectors since the 1990s, interest which has grown ever since. United Kingdom is the number one economy in Europe for the number of projects and amount spent through PPPs, however recently, the trend is changing and other European countries have experienced increased use of such form of partnerships (European Investment Bank 2010). PPPs can provide cost-effective investments, in an efficient way, and therefore are becoming a growing instrument in public procurement in Europe.

With the collapse of the communist system and the transition to an open market economy, Albania has also experienced some forms of partnership between public and private sectors, more in the form of concessions. The efforts of the country towards economic development and accession to the European Union increase the pressure towards the public sector for the improvement of goods and services.

\section{Research Objectives}

This article aims to raise attention not only to the benefits of PPPs through exploring the trends of development, pointing out successful cases, but also to the need of properly understanding the concept of PPPs in order to reach successful agreements. These partnerships are considered to give a positive contribution not only to the economic development but also to the social welfare of a country.

Understanding the concept of PPPs in order to apply it well, is very important for Albania, since these partnerships are considered a beneficial solution in a situation when the public demand for quality goods and services (comparable to EU standards) is rising and at the same time the public debt continues to be above statutory limits. Although PPPs have 
experienced a growing trend, there are limited studies performed in Albania in this field, especially focusing on the implementation of PPPs in the country after the 1990s.

The article explores the concept of PPPs, the dynamics of such partnership development mainly in Europe and priority sectors for PPP development in Albania. The preparation of this article is done based on secondary research, primarily in the form of literature review. Different documents such as policy papers, reports, surveys, strategic documents and literature have been consulted in the process of preparing this article.

\section{Concept of Public Private Partnerships}

Public Private Partnerships are defined as a form of collaboration between public and private sector, taking different legal forms and being implemented in several sectors. According to Pricewaterhouse Coopers (2005) any form of relationship that includes both public and private sectors may be called a PPP. They have been developed long ago as an instrument which public sector could use to provide goods and services and infrastructure development by making use of the experience, know-how and financial resources of the private sector. PPPs have been largely used initially mainly for infrastructure projects which require complex, innovative and large investments, however they are more and more applied also in other areas such as improvement of energy, water, railways, airports, telecommunication, information technology, schools, hospitals and healthcare. PPPs must aim at bringing private resources into public projects, not public resources into private projects (GOI, 2006).

Although there is a wide spread of these types of partnerships, different literature acknowledge that there is not a clear definition of such a partnership.

Weihne (2006) argues that the concept of PPP is nebulous as it allows for great variance across parameters such as time, closeness of cooperation, types of products/services, costs, complexity level of institutionalization as well as number of actors involved".

World Bank Institute, in its Reference Guide (2012) admits that "there is no single, internationally accepted definition of Public-Private Partnership. In this guide PPPs are referred to as "A long-term contract between a private party and a government agency, for providing a public asset or service, in which the private party bears significant risk and management responsibility".

The European Commission (2004) defines PPPs as "forms of cooperation between public authorities and the world of business which aim to ensure the funding, construction, renovation, management or maintenance of an infrastructure or the provision of a service"

OECD (2008) defines PPP as "an arrangement between the government and one or more private partners (which may include the operators and the financers) according to which the private partners deliver the service in such a manner that the service delivery objectives of the government are aligned with the profit objectives of the private partners, and where the effectiveness of the alignment depends on a sufficient transfer of risk to the private partners".

US Department of Transportation (2004) defines PPP as "a contractual agreement formed between public and private sector partners which allows more private sector participation than is traditional. The agreements usually involve a government agency contracting with a private company to renovate, construct, operate, maintain, and/or manage a facility or system. While the public sector usually retains ownership in the facility or system, the private party will be given additional decision rights in determining how the project or task will be completed.

Since there is not a universally accepted definition of PPPs, the term serves more to identify the variety of partnerships that can be established amongst public sector and private entities, which aim to use public infrastructure for offering public services. PPPs serve to mainly create value for the money for the public sector and can be found in different models.

According to Hodge and Greve (2005) PPPs take a variety of forms that reflect varying degrees of private involvement, including: design, build and operate; build, own, operate and transfer; and design, build, finance and operate. $^{1}$

\footnotetext{
${ }^{1} \mathrm{~A}$ brief explanation of different models of PPPs based on the degree of involvement of private sector: Operation and Maintenance contracts are used where the private entity operates a state owned facility; Design - build - finance - operate are used when a new facility is designed, established and operated under a long-term lease contract by a private entity, and at the end of the contract term it is transferred to the public sector. Build - own - operate - transfer are used when the private sector receives a franchise to establish a facility which at the end of the term is transferred back to the public sector. Buy-build-operate -transfer of a public asset to a private entity are used under a contract in which the facilities are upgraded and operated by the private entity for the contract term.
} 
International experience has shown that projects which can be successfully implemented through a PPP usually comply with a set of characteristics:

- the relationship between the public and private organization is long term, rather than a one-time relationship;

- both public and private sector contribute in decision-making and implementation of public goods/service delivery;

- the risk is allocated in a negotiated procedure between the parties involved, public and private.

- the ownership of the asset remains with the public sector.

The partnership between public and private sector might take different forms, where the most used are:

- Creating wider markets: using private sector skills and finance to utilize the assets of public sector;

- Private Finance Initiatives: The public sector contracts to purchase quality services, with defined outputs, on a long-term basis from the private sector which covers the costs through direct charges on the users of the asset. Public sector involvement is limited to assistance with planning, licensing and other statutory procedures.

- Joint Venture - Partnerships in which public and private sector partners pool their assets, finance and expertise under joint management, to deliver long term growth in value for both partners.

- Partnership companies: Introducing private sector ownership into state-owned businesses, while preserving the public interest and public policy objectives, through legislation, regulation, partnership agreements, or retention of a special government share.

- Partnership investments: Partnerships in which the public sector contributes to the funding of investment projects by private sector parties, to ensure that the public sector shares in the return generated by these investments.

- Franchises: A concession awarded by the government to a private sector partner to provide a public service for an agreed period. The private sector partner pays a fee during this period for the revenue (or a share of the revenue) that the service generates.

As public sector faces budget constraints on one hand and a demand for more and better public services, the establishment of PPPs can provide an effective solution, of mutual benefit, where each party roles and responsibilities have been defined.

\section{Benefits of using Public Private Partnerships}

Public-private partnerships increasingly have become the default solution to government problems and needs, most recently for infrastructure, and they are embraced by a wide range of constituencies, across political parties, and throughout the world (Wettenhall, Roger 2003).

PPPs are valued often more for providing the public sector with the special technical expertise, management, knowledge and experience, advanced technology and innovation, ability to generate additional funding and operate efficiently, providing services and goods to the benefit of the open public for which public sector remains responsible.

PPPs tend to be implemented faster and in a more cost-efficient way. A study performed by the National Audit Office (2003) in the United Kingdom showed that out of the publicly procured projects, $70 \%$ were delivered later than planned and $73 \%$ with costs exceeding the initial budget; while from PPP projects only 22\% finished later than planned and only $24 \%$ of the projects were implemented with overspending their initial budget.

It is a well known fact that the private sector operates in a more efficient way than the public sector and therefore, transferring most of the risk to the private sector ensures cost-efficiency. The private sector is more focused towards outputs rather than inputs, and makes better use of principles of result based management techniques, resulting in shorter life cycle for the projects; better risk allocation; improved quality for the goods and services; innovation and advanced technology; creating market standards for public service costs, therefore creating a value for the money, and strengthening of public management.

In the framework of such partnerships the role of the public sector shifts from day to day delivery of the products and services towards more planning, monitoring and evaluation of expected delivery of the private company in the partnership. Through a PPP the public sector will focus more on acquiring services at the most cost-effective manner, rather than directly owning and operating an asset. 


\section{PPP Development Trends in Europe}

Public Private Partnerships in Europe have shown an increase in both size and number since 1990s. As shown in Figure 1, there has been a steady growth of PPPs in Europe until 2007, while in 2007-2009 there has been a slight decline due to the financial crisis. (The bars show the trend of project values in years, while the line shows the trends in terms of number of projects.)

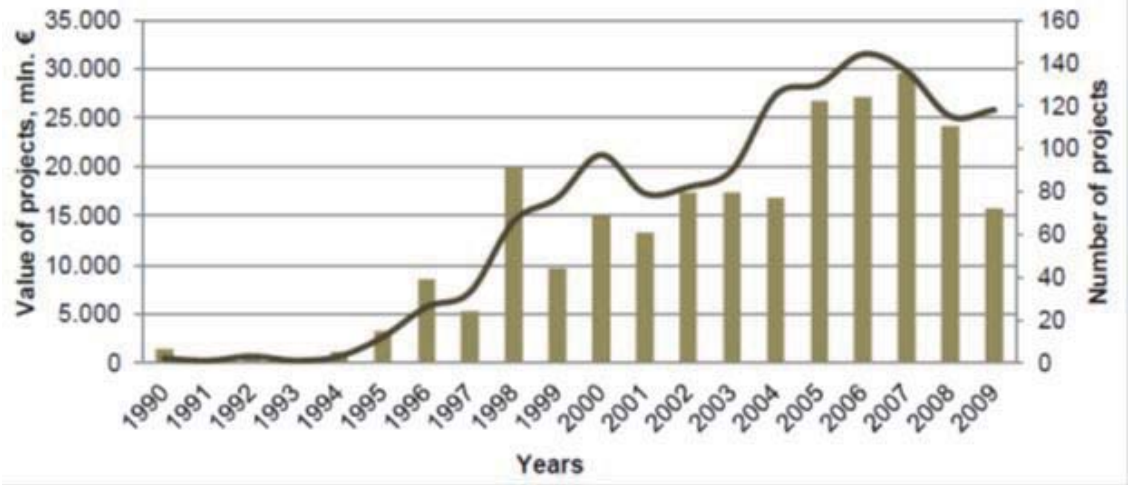

Figure 1. European trend in PPPs 1990-2009. (EIB 2010)

According to European Investment Bank (2010), and as shown in Figure 2, United Kingdom has undertaken the highest number of PPPs amongst other European countries:

- In terms of project number: during the period 1990-2009 United Kingdom accounts for about $66 \%$ of all European PPP projects, followed by Spain which is the second biggest PPP market with 10\% shares. France, Germany, Italy and Portugal all represent $2-5 \%$ of the total number of projects, respectively. The UK, Portugal, France, Germany, Spain and Italy together account for some 92\% of all European PPP projects.

- In terms of project value, UK accounts for $53 \%$ of the total value of European PPPs followed by Spain and Portugal. France, Germany and Greece together represent about 15\% of the value of PPPs in Europe. Hungary remains the country with the largest share of PPP projects amongst new European member states.

Overall, this suggests that the PPP market in Europe continues to slowly diversify across countries.

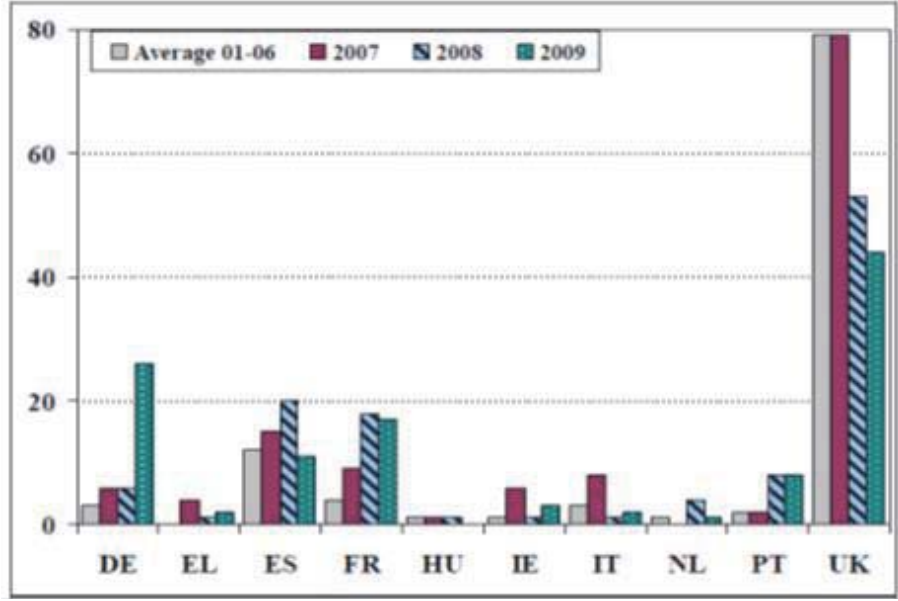

Figure 2. Trend of number of PPP projects per country 2001-2009 (Source: EIB 2010)

Public Private Partnerships have seen a vast application in different sectors, according to EIB (2012) and as shown in Figure 3. 


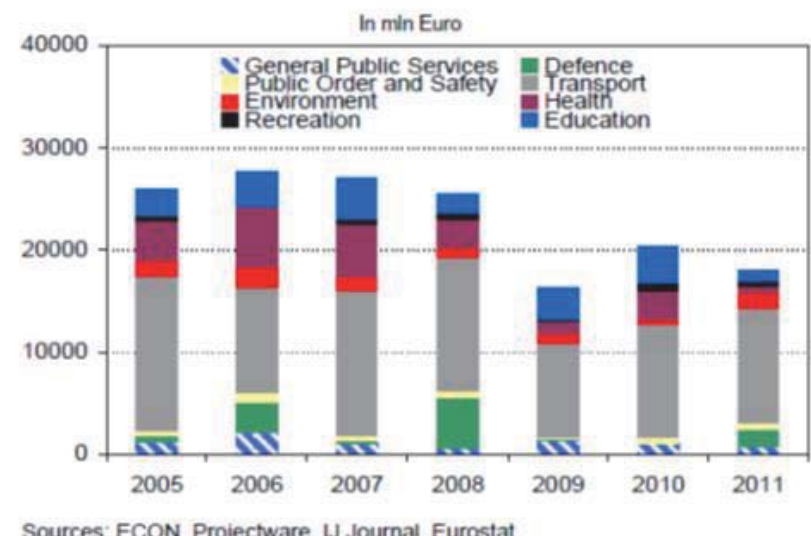

Figure 3. PPP projects in the EU by sector (EIB 2012)

PPPs have initially developed for covering the needs of public sector for investment in infrastructure. During 2005-2011, transport accounts for the largest share of total PPP financing in European Union, with moderate fluctuations over time. It is followed by the health sector, education and defense, showing a steady performance in the education sector and a decline by roughly $9 \%$ in health in 2011 , due to a considerable decline of private investment in this sector.

Since United Kingdom has the largest share of PPPs in Europe it is important to see how the distribution of PPPs is spread across different sectors in the other European countries. Figure 4 gives an overview of the sectoral distribution of PPP projects in these countries.

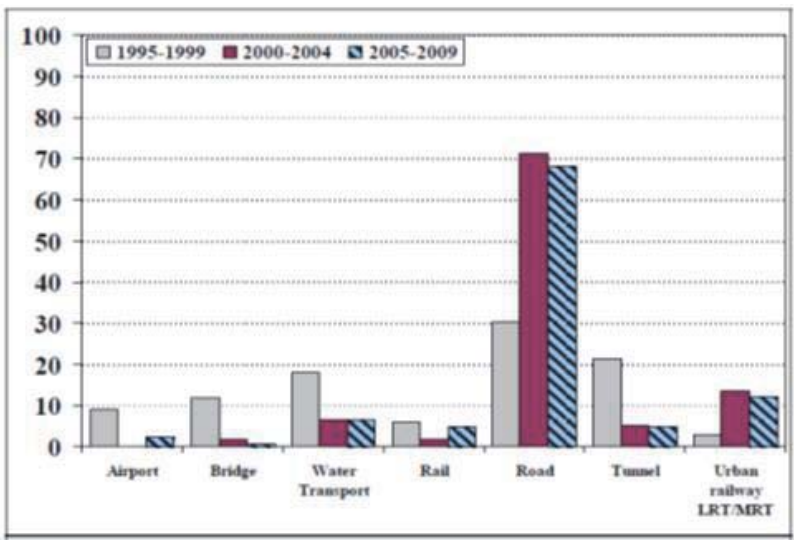

Figure 4. Trend of PPP projects in the EU, outside UK (EIB 2010)

As shown in Figure 4, the distribution of PPP projects outside the United Kingdom remains concentrated in transport which represented $41 \%$ of the number and $76 \%$ of the value of PPPs in Europe. Education and health PPPs are gaining ground and account for $26 \%$ of the number and 11\% of the value of PPPs in continental Europe in 2005-2009 (EIB 2010).

The effects of financial crisis in Europe have affected also the dynamics of PPP market. As per EIB (2010) while the number and value of PPP projects declined in Spain, and in the United Kingdom was almost reduced in half, in other countries such as in Germany, France and Portugal the number of PPPs increased notably in recent years.

The PPP market in Europe accounts for a number of over 1300 contracts with a total value of above 250 billion EUR in the time span 1990-2009.

\section{PPP Development in Albania}

Albania is a country which has struggled a lot since 1990s, during the transition from a centrally planned state economy towards a modern open-market economy. The transition has faced Albania with a lot of social and economic problems as 
a result of changes in the economic structure, failure of state supported industry, rising unemployment, high migration rates and unstable political environment. In 2008, the waves of global crisis affected also the Albanian economy. Remittances declined from 17\% of GDP in 2008 to $7 \%$ of GDP in 2010, mostly from Albanians residing in Greece and Italy. The agricultural sector, accounts for almost half of employment (47\% in 2010) and is limited primarily to small family operations and subsistence farming, because of a lack of modern equipment, unclear property rights, and the prevalence of small, inefficient plots of land. Foreign investment remains low compared to the region and the country aims to improve business conditions including infrastructure in terms of roads, facilities and utilities. The country will continue to face challenges from increasing public debt, having exceeded its former statutory limit of 60\% of GDP in 2013. Strong trade, remittance, and banking sector ties with Greece and Italy make Albania vulnerable to spillover effects of debt crises and weak economic growth.

At a time when the country is facing with economic challenges and the expectations from the population for better quality public services are high, alongside with high public debt rates, PPPs are considered to be a very good solution for all. Besides, Albania has signed the pre-accession agreement with the European Union in 2014 and therefore, public goods and services need to match up to the European standards, improving their quality and value for the money.

PPP in Albania was not allowed during the communist system. Some form of PPP was implemented only after the 1992. Although the country has experienced some form of PPPs, the phenomenon is growing in European countries, and the term is being more and more used by central government officials, there is a lack of knowledge at the public sector administration level in terms of concept and models of PPPs. The Albanian experience regarding some form of PPP is related only to concessions2. Often public officials confuse privatization as a form of PPP, which it is not.

Different European countries have established successful models of PPPs and Albania has the opportunity to learn from best practices from different countries such as Germany, United Kingdom, Spain and Hungary. areas of:

Some of the projects undertaken in Albania in the past recent years in the form of PPPs are concessions in the

- Production of fiscal stamps - concession given to Swiss company "Sicpa Security Solutions SA";

National Lottery was given as a concession to the company "Austrian Lotteries" ;

- Vehicle technical control, an annual obligatory service - was given as a concession to the Swiss company "SGS Automotive Albania";

- Production of ID cards and Passports was given to the French company "Sagem";

- Concessions about the constructions of several small hydro-power plants;

- Reconstruction of Tirana Airport;

The history of concessions in Albania has been faced with both successful and not so successful cases. Different arguments are raised very often in regard to the causes of not successful projects only at the political level, without a thorough investigation on the contributing factors.

However, the case of concessions for small hydropower plants has resulted with individual successes and failures. During 2007-2013 the Albanian government opened widely the possibilities for concessions of small hydropower plants throughout Albania. As of Atrako (2012) a number of 100 concession contracts have been approved in the time frame 2007-2011. A great number of these contracts have not been implemented according to the contract or hav not started at all, raising many questions about the quality of the proposals and evaluation process from both private companies and respective public authorities.

In contrast to that, the project of Ashta hydropower plant has resulted to be a success. This is the first major hydropower plant construction in the last 30 years and the government's first large public-private partnership (PPP) in the energy sector, which has been assisted throughout the process by International Finance Corporation. In September 2008, the government signed a 35-year concession with Verbund (Austria's largest electricity company) to build and operate a new hydropower plant. Over a three-year period, the project mobilized 262 million USD in private investment, increased Albania's power generation capacity by 53 megawatts, and delivered improved services for 170,000 people. Construction of the plant began in January 2010 and became fully operational in March 2013 (www.ifc.org)

Another successful experience has been the concession of "Mother Teresa" Airport in Tirana, a unique case in Albania. The concession was provided in 2004 to a consortium leaded by 'Hochtief Airport Germany' through an international tendering procedure. The concession is contracted for a period of 20 years under the 'design - finance -

2 "Concession": is an act attributable to the State whereby a Contracting Authority entrusts to a third party the total or partial management of public services for which that authority would normally be responsible and for which the third party assumes all or part of the risk. (EBRD 2011) 
build - operate' model, a project which had a value of over 50 million Euro.

PPP continues to be in the agenda of the Albanian government which considers PPPs as an approach for reducing the burden of public expenses and ensuring a better quality for the money with the involvement of private sector. Albania has potential and also political interest in establishing partnerships with the private businesses even in sectors which have not been explored before under such forms of partnerships. The political agenda has included the following sectors as potential areas for future PPPs:

- Agriculture: projects related to food security, as the country has to comply with requirements form the European Union, under the pre-accession terms.

- Healthcare: partnerships in terms of basic health care, checkups, dialysis services, and management of a regional hospital.

- Transportation: building and maintenance of two main road axis such as "Rruga e Arbrit" and "Durres -Morinë"

- Environment: hospital waste management, differentiation of waste of public administration structures and their depending agencies; forestation and forest management.

- Tourism: offering spaces for the promotion of tourism in Albania;

- Social Welfare: provision of elderly houses, development centers for people with disabilities, safe houses for women subject to domestic violence; projects for vocational educational centers.

- Finance: collection of taxes through e-taxation; immovable property registration and collection of property taxes.

\section{Concluding Remarks}

Public Private Partnerships are not a new phenomenon. They are perceived as such, due to the growing demand for such form of partnership, as a solution to the constraints of public sector to provide for the services and goods they are responsible for. PPPs are valued as they provide to the public sector the expertise, management, knowledge and experience, advanced technology and innovation, ability to generate additional funding and operate efficiently, providing services and goods to the benefit of the open public.

Such partnerships are considered to have positive contribution not only to the economic development but also to the social welfare of a country. The public structures both at central and local levels have the potential to save funds from infrastructure investments and other services, which could be invested for the improvement of social welfare. PPPs are widely known to be the new face of development and growth where the collaboration between public and private actors aims to the achievement of common goals.

PPPs have proven to be an effective approach in terms of providing investments and public services, in countries like UK, Germany, Spain, etc. Albania is a country with great potential for PPPs. Given the economic situation and the growing demand for qualitative goods and services, Albania is a potential market for PPP development that can provide for the scarce funding, lack of knowledge, experience and management abilities of the public sector. Although Albania has not consolidated some good models of PPPs, in the past, it can establish a good framework for the development of efficient and effective partnerships which operate on clear, transparent, and accountable terms, based on successful European best practices.

Good PPPs should be built on basis of trust, mutual agreement, transparency and accountability. The relationship between parties should be long-term; both partners should contribute in decision making and implementation of public goods and services; the risk should be allocated in a negotiated procedure and the ownership of the asset at the end remains with the public sector.

\section{References}

EBRD (2011) Albania, Assessment of the quality of PPP Legislation and of the effectiveness of its implementation.

European Investment Bank (2012). PPPs and their Financing in Europe: Recent Trends and EIB Involvement. ECON Department, Economic Studies Division.

European Investment Bank (2011). Recent trends in the PPP market in Europe: slow recovery and increasing EIB involvement. Economics Department, Andreas Kappeler.

European Investment Bank (2010). Economic and Financial Report 2010/04. Public - Private Partnerships in Europe - before and during the recent financial crisis. Andreas Kappeler and Mathieu Nemoz.

European Investment Bank (2010). Public-Private Partnerships in Europe - before and during the recent financial crisis Economic and Financial Report. 
European Commission (2004). Green Paper on Public-Private Partnerships and Community Law on Public Contracts and Concessions. GOI and ADB (2006). Facilitating Public-Private Partnership for Accelerated Infrastructure Development in India, Regional Workshops of Chief Secretaries on PPP, Workshop Report.

Harvard Center for Population and Development Studies (2002). Public-Private Partnerships for Public Health, Edited by Michael R. Reich. ISBN 0-674-00865-0.

Hodge Graeme, Greve Carsten (2005). The Challenge of Public-Private Partnerships: Learning from International Experience. Edward Elgar, UK.

Mata, E., ATRAKO (2013), Partneriteti Publik-Privat dhe Koncesionet në Shqipëri - Kuadri ligjor dhe institucional.

National Audit Office. (2003). PFI: Construction Performance Report by the Comptroller and Auditor General. London: HMSO.

OECD. (2008). Public-Private Partnerships: in pursuit of risk sharing and value for money.

PricewaterhouseCoopers (2005). Delivering the PPP promise: a review of PPP issues and activity

United States Department of Transportation (2004). Report to Congress on Public-Private Partnerships.

Weihe, G. (2006). Public-Private Partnerships: Addressing a Nebulous Concept (Vol. Working Paper No.16), Copenhagen Business School.

Wettenhall, Roger. 2003. The Rhetoric and Reality of Public-Private Partnerships. Public Organization Review 3(1)

World Bank Institute (2012). PPIAF. Public-Private Partnerships - Guide Reference, Version 1.0 IFC (www.ifc.org) 